\title{
The securitisation of aid and the associated risks to human security and development
}

\author{
KARI PAHLMAN
}

\section{Abstract}

Since 9/11 there has been an increasing movement toward the securitisation of development aid. That is, the tendency for donor governments to view security and development as interconnected within a 'security-development nexus'. It reflects the growing concern toward so-called 'failed' or 'fragile' states where underdevelopment has come to be seen as dangerous, especially in light of new wars, refugee crises, migration and terrorism. This paper is concerned with how the securitisation of aid poses risks for development work, specifically within the human development and human security agenda that emerged in the 1990s as an alternative framework to the traditional models of economic development. This paper finds that both in terms of where aid is located and the way in which it is delivered on the ground, the securitisation of aid poses significant risk to the human security and human agenda insofar as it fails to address the underlying causes of insecurity and underdevelopment. It concludes that the associated risks to the human security agenda can be seen by questioning whose security interests are being served through the securitisation of aid.

International aid is one of the most powerful weapons in the war against poverty. Today, that weapon is underused and badly targeted ... and much of what is provided is weakly linked to human development. ${ }^{1}$

$1 \quad$ United Nations Development Programme, Human Development Report 2005: International Cooperation at a Crossroads: Aid, Trade and Security in an Unequal World (Pittsburgh: Hoechstetter Printing Co., 2005) 75. 
In the early 1990s, the human security and development agenda emerged as a new framework for addressing underdevelopment in many parts of the world. ${ }^{2}$ At the same time, there has also been an increasing trend for traditional donor governments to view development and security as interconnected, within a new security-development nexus. ${ }^{3}$ One consequence has been the securitisation of aid. ${ }^{4}$ This paper is concerned with how the human security and human development agenda is impacted. It will argue that through the strategic allocation of aid by donors, and the blurring of military and development activities on the ground, the securitisation of aid undermines the capacity for human development and the achievement of sustainable human security. This paper will first detail the concepts of human security and development, as well as the securitisation of aid. It will then discuss the major risks of this trend. It will highlight United States of America (US) aid to Afghanistan and the use of Provincial Reconstruction Teams (PRTs) as a classic example of the securitisation of aid and its associated risks.

The human security and development agenda emerged in the early 1990s as a new way of conceptualising and approaching development. ${ }^{5}$ This framework has come about as an alternative to the now widely criticised economic growth model of development, and the focus on the Growth National Product (GNP) indicators, affirming that even high GNP and economic growth often fails to address the socioeconomic deprivation and lack of empowerment experienced by many people around the world. ${ }^{6}$ Human development places

2 Timothy Shaw, Sandra MacLean and David Black, 'A Decade of Human Security: What Prospects for Global Governance and New Multilateralisms?', in A Decade of Human Security: Global Governance and New Multilateralisms, eds. Sandra MacLean, David Black and Timothy Shaw (Aldershort: Ashgate Publishing Limited, 2006) 3; Joseph Camilleri, 'Human Security: From Theory to Practice', in Why Human Security Matters: Rethinking Australian Foreign Policy, eds. Denis Altman, Joseph Camilleri and Robyn Eckersley (Sydney: Allen \& Unwin, 2012) 13.

3 Mark Duffield, 'Reprising Durable Disorder: Network War and The Securitisation of Aid', in Global Governance in the 21st Century: Alternative Perspectives on World Order, eds. Björn Hettne and Bertil Odén (Stockholm: Almkvist \& Wiksell International, 2002) 87; Shaw et al., 'A Decade of Human Security', 4; Joanna Spear and Paul Williams, 'Conceptualizing the Security-Development Relationship: An Overview of the Debate', in Security and Development in Global Politics: A Critical Comparison, eds. Joanna Spear and Paul Williams (Washington DC: Georgetown University Press, 2012) 7; Bernard Harborne, 'Aid: A Security Perspective', in Security and Development in Global Politics: A Critical Comparison, eds. Joanna Spear and Paul Williams (Washington DC: Georgetown University Press, 2012) 38; Mark Duffield, Global Governance and the New Wars: The Merging of Development and Security (London: Zed Books Ltd, 2001) 15; David Chandler, 'The Security-Development Nexus and the Rise of "Anti-Foreign Policy"', Journal of International Relations and Development 10:4 (2007) 362; Maria Stern and Joakim Öjendal, 'Mapping the Security-Development Nexus: Conflict, Complexity, Cacophony, Convergence?' Security Dialogue 41:1 (2010) 5.

4 Harborne, 'Aid: A Security Perspective', 38; Duffield, 'Reprising Durable Disorder', 87; Ramses Amer, Ashok Swain and Joakim Öjendal, 'Researching the Security-Development Nexus Through a Multi-Disciplinary Approach', in The Security Development Nexus: Peace, Conflict and Development, eds. Ramses Amer, Ashok Swain and Joakim Öjendal (London: Anthem Press, 2012), 2.

5 Shaw et al., 'A Decade of Human Security', 3; Camilleri, 'Human Security', 13.

6 United Nations Development Programme, Afghanistan National Human Development Report 2004-Security With a Human Face: Challenges and Responsibilities (Islamabad: Army Press, 2004) 3; Camilleri, 'Human Security', 13. 
the individual at the heart of the development objective, as both the means and ends of development, and focuses on enlarging people's capabilities and choices. ${ }^{7}$ Human security expands on human development, acknowledging that traditional realist notions of security are no longer adequate to address the new threats faced by people around the world. ${ }^{8}$ Human security emphasises the need to ensure freedoms so that people can safely exercise their capabilities and choices. ${ }^{9}$ It stresses two main forms of security: freedom from fear and freedom from want. ${ }^{10}$ Critically, it aims to address not only the acute security threats that impact the individual, but also the more chronic non-military threats that perpetuate insecurity, including but not limited to poverty, disease and political repression. ${ }^{11}$

At the same time as the human security agenda has been popularised, there has also been an increasing trend for traditional donor governments to view development and security as interconnected. ${ }^{12}$ This coupling of development and security within foreign policy and development discourse has come to be referred to as the 'security-development nexus'. ${ }^{13}$ It reflects the increasing concern toward so-called 'failed' or 'fragile' states where underdevelopment is now seen as dangerous. ${ }^{14}$ This has become particularly evident in light of

$7 \quad$ United Nations Development Programme, Afghanistan National Human Development Report 2004, 3, 5; Oscar Gomez and Des Gasper, 'Human Security: A Thematic Guidance Note for Regional and National Human Development Report Teams', United Nations Development Programme Human Development Report Office, hdr. undp.org/sites/default/files/human_security_guidance_note_r-nhdrs.pdf, (2013) accessed 2 May 2014, 3.

8 United Nations Development Programme, Afghanistan National Human Development Report 2004, 5.

9 Ibid., 3, 5.

10 Shaw et al., 'A Decade of Human Security', 4; Camilleri, 'Human Security', 17; David Chandler, 'Review Essay: Human Security: The Dog that Didn't Bark', Security Dialogue 39:4 (2008) 435; Saferworld UK, 'The Securitisation of Aid? Reclaiming Security to Meet Poor People's Needs', saferworld.org.uk, www.saferworld. org.uk/Securitisation\%20briefing\%20pages.pdf, (2011) accessed 4 April 2014, 3; John McKay, 'Security and Development', in International Development: Issues and Challenges, 2nd Ed, eds. Damien Kingsbury, John McKay, Janet Hunt, Mark McGillivray and Matthew Clarke (Basingstoke: Palgrave Macmillan, 2012) 339; Gomez and Gasper, 'Human Security', 1.

11 United Nations Development Programme, Afghanistan National Human Development Report 2004, 5, 6; Chandler, 'The Security-Development Nexus and the Rise of "Anti-Foreign Policy"', 367.

12 Harborne, 'Aid: A Security Perspective', 38, 39; Chandler, 'The Security-Development Nexus and the Rise of "Anti-Foreign Policy"', 367; Nancy Thede, 'Policy Coherence for Development and Securitisation: Competing Paradigms or Stabilising North-South Hierarchies?' Third World Quarterly 34:5 (2013) 784.

13 Jude Howell and Jeremy Lind, 'Manufacturing Civil Society and the Limits of Legitimacy: Aid, Security and Civil Society after 9/11 in Afghanistan', European Journal of Development Research 21:5 (2009) 719; Spear and Williams, 'Conceptualizing the Security-Development Relationship', 7.

14 Duffield, 'Reprising Durable Disorder', 89; Spear and Williams, 'Conceptualizing the Security-Development Relationship', 7; Janet Hunt, 'Aid and Development', in International Development: Issues and Challenges, 2nd Ed., eds. Damien Kingsbury, John McKay, Janet Hunt, Mark McGillivray and Matthew Clarke (Basingstoke: Palgrave Macmillan, 2012) 103; Chandler, 'Review Essay', 435; Mark Duffield, 'Liberal Way of Development and the Development-Security Impasse: Exploring the Global Life-Chance Divide', Security Dialogue 41:1 (2010) 53. 
new wars, refugee crises, migration and threats of international terrorism. ${ }^{15}$ Development is now understood to be a critical prerequisite to national security, viewed alongside defence and diplomacy as a means of pursuing political, economic and security interests. ${ }^{16}$ One of the major consequences of this development-security nexus, especially since the events of 11 September 2001, has been the securitisation of aid. ${ }^{17}$ That is, the use of aid as a form of 'soft power' in the pursuit of the donor's own political and security objectives. ${ }^{18}$ As Mark Duffield notes, however, the securitisation of aid is not just a matter of policy; the implications are significant. ${ }^{19}$ The securitisation of aid poses two major risks to human security and development that will be discussed here. The first is the strategic allocation of aid that sees some countries prioritised over others for assistance, as well as the conditionality of such aid.

Aid distribution is increasingly influenced and skewed by geopolitical security objectives. ${ }^{20}$ That is, donor countries allocate aid according to where they perceive their national security interests to be at threat, or where they are militarily engaged. ${ }^{21}$ This can be seen in the ever-increasing shift from multilateral to bilateral aid giving, allowing donor governments greater flexibility to pursue their own security objectives. ${ }^{22}$ Essentially, it is argued that donors are now using aid as a form of 'soft power' to try and tackle terrorism and defend their own national security interests, 'rather than as a part of a more generous look at sustainable and peaceful development' around the world. ${ }^{23}$ In fact, there are growing concerns within the development literature that aid, and development assistance more broadly, is returning to a kind of 'Cold War

15 Howell and Lind, 'Manufacturing Civil Society and the Limits of Legitimacy', 719; Hunt, 'Aid and Development', 103; Joanna Macrae and Adele Harmer, 'Beyond the Continuum: An Overview of the Changing Role of Aid Policy in Protracted Crises', in Beyond the Continuum: The Changing Role of Aid Policy in Protracted Crises, eds. Joanna Macrae and Adele Harmer (London: Overseas Development Institute, 2004) 4; Shaw et al., 'A Decade of Human Security', 6; Duffield, 'Liberal Way of Development and the Development-Security Impasse', 56.

16 Howell and Lind, 'Manufacturing Civil Society and the Limits of Legitimacy', 719; Spear and Williams, 'Conceptualizing the Security-Development Relationship', 7; Harborne, 'Aid: A Security Perspective', 38; Thede, 'Policy Coherence for Development and Securitisation', 784.

17 Duffield, 'Reprising Durable Disorder', 89; Harborne, 'Aid: A Security Perspective', 42; Amer et al., 'Researching the Security-Development Nexus Through a Multidisciplinary Approach', 2.

18 Saferworld UK, 'The Securitisation of Aid?' 5; Paul Fishstein and Andrew Wilder, Winning Hearts and Minds? Examining the Relationship Between Aid and Security in Afghanistan (Medford: Feinstein International Centre, 2012) 2.

19 Duffield, Global Governance and the New Wars, 16.

20 Howell and Lind, 'Manufacturing Civil Society and the Limits of Legitimacy', 720, 721; Hunt, 'Aid and Development', 109; Oxfam International, Whose Aid is it Anyway? Politicizing Aid in Conflicts and Crises (Oxford: Oxfam GB, 2011) 5; Amer et al., 'Researching the Security-Development Nexus Through a Multidisciplinary Approach', 2; Thede, 'Policy Coherence for Development and Securitisation', 784.

21 Hunt, 'Aid and Development', 109; Oxfam International, Whose Aid is it Anyway? 5; Amer et al., 'Researching the Security-Development Nexus Through a Multidisciplinary Approach', 2.

22 Harborne, 'Aid: A Security Perspective', 44; Shahrbanou Tadjbakshs and Anuradha Chenoy, Human Security: Concepts and Implications (Abingdon: Routledge, 2007) 228.

23 Saferworld UK, 'The Securitisation of Aid? 5; Fishstein and Wilder, Winning Hearts and Minds? 2. 
mentality' insofar as traditional national security interests are outweighing human development as the main objective. ${ }^{24}$ It has been noted that in pursuing geopolitical objectives, aid flows in many cases are largely unconnected to the degree of poverty or insecurity felt by people in the beneficiary countries. ${ }^{25}$ Ultimately, the securitisation of aid means such development assistance is in reality working for traditional security objectives, rather than the long-term human security and development of those in developing countries. ${ }^{26}$

This kind of skewed aid has several important consequences for human security and development. In particular, as articulated by Duffield, development aid can no longer be seen as neutral, but rather as an extension of Western foreign policy. ${ }^{27}$ This can be exemplified in the diversion of aid to the so-called 'War on Terror', where 34 per cent of all increases in ODA (official development assistance) since 2000 have gone to Afghanistan and Iraq. ${ }^{28}$ While aid given by the US since 2002 has increased, the majority has gone to the Department of Defense (DoD) for assistance in Iraq and Afghanistan. ${ }^{29}$ Increased from 5.5 per cent in 2002, the DoD accounted for 21 per cent of US aid by 2006. ${ }^{30}$ Furthermore, while neither Iraq nor Afghanistan were among the top 10 recipients of US ODA in 2001, by 2005 they were first and second highest recipients respectively. ${ }^{31}$ These two front line states on the 'War on Terror' were the top two recipients in 2012, with Afghanistan number one. ${ }^{32}$ The bilateral share of US ODA was also raised from 72 per cent in 2001 to 92 per cent in $2005 .{ }^{33}$ The fact that there are a few 'favoured' countries disproportionately benefiting from ODA has led some to argue that poverty has been replaced by terrorism as the main development objective. ${ }^{34}$ Therefore, countries that are perhaps more stable or are simply not a foreign policy objective, yet still desperately poor, are being overlooked and losing out on much-needed development aid and assistance. ${ }^{35}$ Essentially, countries that do not present as a security threat to donor states miss out on

\footnotetext{
24 Harborne, 'Aid: A Security Perspective', 43.

25 Duffield, Global Governance and the New Wars, 35.

26 Harborne, 'Aid: A Security Perspective', 38.

27 Duffield, 'Liberal Way of Development and the Development-Security Impasse', 54.

28 Patrick Kilby, 'The Changing Development Landscape in the First Decade of the 21st Century and its Implications for Development Studies', Third World Quarterly 33:6 (2012) 1010; Harborne, 'Aid: A Security Perspective', 44.

29 Kilby, 'The Changing Development Landscape in the First Decade of the 21 st Century and its Implications for Development Studies', 1010.

30 Ibid.

31 Organisation for Economic Co-operation and Development (OECD), Development Co-operation Report 2002: Efforts and Policies of the Members of the Development Assistance Committee (Paris: OECD Publishing, 2003) 119; OECD, Development Co-operation Report 2006: Efforts and Policies of the Members of the Development Assistance Committee (Paris: OECD Publishing, 2007) 97.

32 OECD, Development Co-operation Report 2013: Ending Poverty (Paris: OECD Publishing, 2013$) 230$.

33 OECD, Development Co-operation Report 2002, 119; OECD, Development Co-operation Report $2006,97$.

34 Harborne, 'Aid: A Security Perspective', 44.

35 Oxfam International, Whose Aid is it Anyway? 5.
} 
aid despite equal, if not greater vulnerability, cementing the growing concern that aid allocation is increasingly less correlated to need. ${ }^{36}$ Such trends are also critically reducing the already limited resources available to poor countries, undermining prospects for human security and development. ${ }^{37}$ Furthermore, it has been noted that socioeconomic indicators in Afghanistan and Iraq have failed to show significant progress despite the amount of aid committed to them, demonstrating that human development has been trumped by national security as the main aid objective. ${ }^{38}$

Related to the strategic allocation of aid, another risk to the human security objective associated to the securitisation of aid is the conditionality of aid. ${ }^{39}$ Specifically, the way in which aid has become conditional on military cooperation, seen in the way US aid has in many cases become conditional on the willingness of recipient countries to join the fight against terrorism. ${ }^{40}$ By 2004, the US Agency for International Development (USAID) had classified countries 'according to the extent to which they were supporters of the war'. The political and military conditionality of American aid has been exemplified by America's support for countries in Central Asia based on their allegiance to the Coalition's military interventions in Afghanistan in 2001. ${ }^{41}$ Uzbekistan, for example, by allowing the deployment of US troops on its territory, was promised aid to the value of US\$1.6 million and its government went from the status of 'non-reformer' to key ally of the US by October $2001 .{ }^{42}$ These forms of conditionality demonstrate the way development aid is increasingly tied to the 'politics of bilateral support and foreign policy priorities', ${ }^{43}$ rather than notions of human development and security. Moreover, the securitisation of aid in this way risks supporting dubious regimes simply for taking a role in the War on Terror, threatening progress toward genuine human development and security as they are no longer the main criteria for aid donation. ${ }^{44}$ Aid conditionalities can also be seen to implicate civilians on the ground in conflict zones, as it is used to 'buy' cooperation with military forces, or information. ${ }^{45}$ This was demonstrated in 2004 when US Army personnel distributed leaflets threatening the loss of aid

\footnotetext{
36 Ibid.; Macrae and Harmer, 'Beyond the Continuum', 5.

37 Amer et al., 'Researching the Security-Development Nexus Through a Multidisciplinary Approach', 2.

38 Harborne, 'Aid: A Security Perspective', 42.

39 United Nations Development Programme, Afghanistan National Human Development Report 2004, 201; Jonathan Goodhand, 'Aiding Violence or Building Peace? The Role of International Aid in Afghanistan', Third World Quarterly 23:5 (2002) 847; Tadjbakshs and Chenoy, Human Security, 217; Oxfam International, Whose Aid is it Anyway? 2; United Nations Development Programme, Human Development Report 2005, 76.

40 Tadjbakshs and Chenoy, Human Security, 217; McKay, 'Security and Development', 337.

41 Ibid.

42 Ibid.

43 Ibid.

44 McKay, 'Security and Development', 337; United Nations Development Programme, Human Development Report 2005, 79.

45 Oxfam International, Whose Aid is it Anyway? 2.
} 
if people did not come forward and share information about Al-Qaeda or the Taliban. ${ }^{46}$ Conditionalities essentially place greater emphasis on aid as a means of protecting traditional security concerns, taking the focus away from the fears and wants of the individuals, and undermining prospects for human security and human development. ${ }^{47}$

The second major risk to human security and development associated with the securitisation of aid is the blurring of aid and military objectives. ${ }^{48}$ There has been an increasing trend for military units to take part in the delivery of both development and humanitarian aid. ${ }^{49}$ In conflict zones particularly, where NGOs or other agencies may not be able to operate due to ongoing insurgency, the armed forces are playing a greater role in the provision of aid. ${ }^{50}$ Aid agencies are now also working alongside and cooperating with the military to provide development assistance, and vice versa. ${ }^{51}$ Because aid organisations are now working in the same space as the military, local populations are increasingly identifying them as affiliated and as political actors in and of themselves. ${ }^{52}$ This is even more apparent with NGOs that in some cases must display identification, such as those which were required to fly the US flag if they accepted funding from USAID..$^{53}$ This means, as noted by Mark Duffield, that it is increasingly difficult for NGOs to separate their own development ... activities from the pervasive logic of the North's own security regime'. Essentially, as a result of the securitisation of aid, the distinction between NGOs, civilian agencies and military combatants has become more difficult to distinguish, and any neutrality and impartiality is severely compromised..$^{54}$ This risks not only the safety of aid workers, but also their relationship with local civilians, ultimately compromising their ability to ensure the freedoms and choices of people on the ground. ${ }^{55}$

\footnotetext{
46 United Nations Development Programme, Afghanistan National Human Development Report 2004, 218.

47 Ibid., 201.

48 Ibid., 216; Fishstein and Wilder, Winning Hearts and Minds? 18; Kilby, 'The Changing Development Landscape in the First Decade of the 21st Century and its Implications for Development Studies', 1011.

49 Fishstein and Wilder, Winning Hearts and Minds? 17; Howell and Lind, 'Manufacturing Civil Society and the Limits of Legitimacy', 722, 732; Harborne, 'Aid: A Security Perspective', 42.

50 Fishstein and Wilder, Winning Hearts and Minds? 22; Howell and Lind, 'Manufacturing Civil Society and the Limits of Legitimacy', 728.

51 Kilby, 'The Changing Development Landscape in the First Decade of the 21 st Century and its Implications for Development Studies', 1011; Howell and Lind, 'Manufacturing Civil Society and the Limits of Legitimacy', 732. 52 Ibid., 731.

53 Danielle Beswick and Paul Jackson, Conflict, Security and Development: An Introduction (Abingdon: Routledge, 2011) 77.

54 United Nations Development Programme, Afghanistan National Human Development Report 2004, 52; Howell and Lind, 'Manufacturing Civil Society and the Limits of Legitimacy', 729.

55 Abby Stoddard, Adele Harmer and Victoria DiDomenico, 'Providing Aid in Insecure Environments: 2009 Update', Humanitarian Policy Group, www.odi.org/sites/odi.org.uk/files/odi-assets/publications-opinionfiles/4243.pdf, (2009) accessed 20 March 2014, 1.
} 
The delivery of development assistance in such a securitised way has also seen aid become short-sighted, with an emphasis on 'quick-impact' and visible projects, evident in aid given to Afghanistan..$^{56}$ It has been argued that military involvement has focused on short-term projects to consolidate military successes and 'win the hearts and minds' of local people to gain their trust. ${ }^{57}$ In fact, as defined by the US Army Manual Commanders' Guide to Money as a Weapons System, aid is a nonlethal weapon that should be used to win hearts and minds. ${ }^{58}$ Essentially, within the security-development nexus, short-term development assistance and 'quick-impact' aid projects administered by military personnel are increasingly being used to capture a more cooperative civilian population who would be willing to share intelligence information with them. ${ }^{59}$ However, the short-term nature of development aid delivered in this way, and the pressure to spend money quickly, have significant consequences. ${ }^{60}$ Donors have become tied to a culture of short-term budgets, financial accountability and timely disbursement of funds, measured by indicators of expenditure rather than social impact. ${ }^{61}$ In fact, aid delivery within this 'war-aid economy' as it has been termed, has actually perpetuated instability in some cases, fuelling corruption, reinforcing unequal power relations, favouring or at least being seen to favour some groups over others, and providing resources to be fought over. ${ }^{62}$ It has also been seen to increase aid dependency, rather than promote long-term capacitybuilding or economic independence. ${ }^{63}$ The way in which the securitisation of aid prioritises quick and visible spending demonstrates it is not geared toward long-term human development or security.

PRTs in Afghanistan are a pertinent example of the blurring of development and military activities and the risks it poses to the human security and the development agenda. Designed as joint civilian-military units, PRTs were introduced in Afghanistan by the US in 2002 as a means of aid delivery to try and improve stability and reconstruction. ${ }^{64}$ In doing so, PRTs were tasked to 'win the hearts and minds' of Afghans through the delivery of small-scale, quickimpact reconstruction and development projects, largely measured in terms of

\footnotetext{
56 Fishstein and Wilder, Winning Hearts and Minds? 22, 24.

57 Ibid., 23, 41; Howell and Lind, 'Manufacturing Civil Society and the Limits of Legitimacy', 731.

58 Oxfam International, 'Quick Impact, Quick Collapse: The Dangers of Militarized Aid in Afghanistan', oxfam. org, www.oxfam.org/sites/www.oxfam.org/files/quick-impact-quick-collapse-jan-2010.pdf, (26 January 2010) accessed 4 April 2014, 1.

59 Fishstein and Wilder, Winning Hearts and Minds? 23; Howell and Lind, 'Manufacturing Civil Society and the Limits of Legitimacy', 731.

60 United Nations Development Programme, Afghanistan National Human Development Report 2004, 216.

61 Ibid.

62 Fishstein and Wilder, Winning Hearts and Minds? 3, 5.

63 United Nations Development Programme, Afghanistan National Human Development Report 2004, 207, 206.

64 Howell and Lind, 'Manufacturing Civil Society and the Limits of Legitimacy', 732.

Fishstein and Wilder, Winning Hearts and Minds? 22.
} 
time and money spent. ${ }^{65}$ This was particularly the case in the south and east of the country, where NGOs and other agencies were unable to operate because of insecurity and instability. ${ }^{66}$ However, as noted in the Afghanistan Human Development Report as early as 2004, PRTs 'are proving to be an inadequate and dangerous vehicle for the provision of security and their new [development] role is increasingly hard to distinguish from that of genuine humanitarian and development aid workers'.

The implications and risks to human security and development associated with the blurring of aid and military activities, as exemplified by PRTs in Afghanistan, are extremely consequential. Development projects implemented through this 'dual-pronged' developmental and militaristic strategy have been noted to be poorly implemented, unsustainable, low quality and of little development value. ${ }^{67}$ They have also been criticised for not addressing Afghanistan's fundamental needs or human security problems such as high unemployment. ${ }^{68}$ Inhibited by lack of local knowledge, unfamiliarity with the environment and social networks and structures, as well as their dependency on interpreters, it has been argued that military-led development has resulted in poor outcomes. ${ }^{69}$ Critically, the war-aid economy has also been shown to perpetuate severe corruption and create perverse incentives to maintain insecure environments. ${ }^{70}$ The majority of American development aid funds have been concentrated in the more insurgency-affected areas of Southern Afghanistan, because as discussed previously, the main criteria for the targeting of US aid has increasingly been national security, rather than poverty or development as an end in itself. ${ }^{71}$ However, such prioritisation of these more insecure areas, despite lacking evidence that aid is promoting stability or security, has meant that the need to perpetuate insecurity has been recognised, particularly by security contractors who have been seen to 'create a problem to solve a problem'. ${ }^{72}$ Such consequences demonstrate the risk of the securitisation of aid to the freedoms and security of the Afghan people.

It can therefore be seen that the securitisation of aid certainly poses significant risks to human security and development. Both in terms of where aid is allocated based on tradition security objects of donor states, and the way in which it is delivered on the ground, the securitisation of aid fails to address the

65 Ibid., 49; Howell and Lind, 'Manufacturing Civil Society and the Limits of Legitimacy', 722.

66 Fishstein and Wilder, Winning Hearts and Minds? 22.

67 Fishstein and Wilder, Winning Hearts and Minds? 41, 42, 46, 47; Howell and Lind, 'Manufacturing Civil Society and the Limits of Legitimacy', 719, 731.

68 Fishstein and Wilder, Winning Hearts and Minds? 46, 50.

69 Ibid., 48.

70 Ibid., 3.

71 Howell and Lind, 'Manufacturing Civil Society and the Limits of Legitimacy', 731.

72 Fishstein and Wilder, Winning Hearts and Minds? 3; Howell and Lind, 'Manufacturing Civil Society and the Limits of Legitimacy', 719, 731. 
underlying causes of insecurity and underdevelopment. Exemplified primarily by US aid to Afghanistan, the securitisation of aid places traditional state security concerns at the centre of the development objective rather than the individual, undermining the capacity for human development and neglecting the fears and wants faced by people in their daily lives. Such a narrow security objective cannot ensure the human security and development of the Afghan people, nor those experiencing human insecurity in other parts of the world. ${ }^{73}$ Ultimately, by questioning whose security interests are being served through the securitisation of aid, the associated risks to the human security agenda can be seen.

\section{Bibliography}

Amer, Ramses, Swain, Ashok and Öjendal, Joakim. 'Researching the SecurityDevelopment Nexus Through a Multi-Disciplinary Approach'. In The Security Development Nexus: Peace, Conflict and Development. Eds. Amer, Ramses, Swain, Ashok and Öjendal, Joakim (London: Anthem Press, 2012) 1-12.

Beswick, Danielle and Jackson, Paul. Conflict, Security and Development: An Introduction (Abingdon: Routledge, 2011).

Camilleri, Joseph. 'Human Security: From Theory to Practice'. In Why Human Security Matters: Rethinking Australian Foreign Policy. Eds. Altman, Denis, Camilleri, Joseph and Eckersley, Robyn (Sydney: Allen \& Unwin, 2012) 12-33.

Chandler, David. 'Review Essay: Human Security: The Dog that Didn't Bark'. Security Dialogue 39:4 (2008) 427-438.

Chandler, David. 'The Security-Development Nexus and the Rise of "AntiForeign Policy"'. Journal of International Relations and Development 10:4 (2007) 362-386.

Duffield, Mark. 'Liberal Way of Development and the Development-Security Impasse: Exploring the Global Life-Chance Divide'. Security Dialogue 41:1 (2010) 53-76.

Duffield, Mark. 'Reprising Durable Disorder: Network War and The Securitisation of Aid'. In Global Governance in the 21st Century: Alternative Perspectives on World Order. Eds. Hettne, Björn and Odén, Bertil (Stockholm: Almkvist \& Wiksell International, 2002) 74-105.

73 United Nations Development Programme, Afghanistan National Human Development Report 2004, 228 
Duffield, Mark. Global Governance and the New Wars: The Merging of Development and Security (London: Zed Books Ltd, 2001).

Fishstein, Paul and Wilder, Andrew. Winning Hearts and Minds? Examining the Relationship Between Aid and Security in Afghanistan (Medford: Feinstein International Centre, 2012).

Gomez, Oscar and Gasper, Des. 'Human Security: A Thematic Guidance Note for Regional and National Human Development Report Teams'. United Nations Development Programme Human Development Report Office, hdr. undp.org/sites/default/files/human_security_guidance_note_r-nhdrs.pdf, (2013) accessed 2 May 2014.

Goodhand, Jonathan. 'Aiding Violence or Building Peace? The Role of International Aid in Afghanistan'. Third World Quarterly 23:5 (2002) 837-859.

Harborne, Bernard. 'Aid: A Security Perspective'. In Security and Development in Global Politics: A Critical Comparison. Eds. Spear, Joanna and Williams, Paul (Washington DC: Georgetown University Press, 2012) 37-56.

Howell, Jude and Lind, Jeremy. 'Manufacturing Civil Society and the Limits of Legitimacy: Aid, Security and Civil Society after 9/11 in Afghanistan'. European Journal of Development Research 21:5 (2009) 718-726.

Hunt, Janet. 'Aid and Development'. In International Development: Issues and Challenges, 2nd Ed. Eds. Kingsbury, Damien, McKay, John, Hunt, Janet, McGillivray, Mark and Clarke, Matthew (Basingstoke: Palgrave Macmillan, 2012) 79-111.

Kilby, Patrick. 'The Changing Development Landscape in the First Decade of the 21 st Century and its Implications for Development Studies'. Third World Quarterly 33:6 (2012) 1001-1017.

Macrae, Joanna and Harmer, Adele. 'Beyond the Continuum: An Overview of the Changing Role of Aid Policy in Protracted Crises'. In Beyond the Continuum: The Changing Role of Aid Policy in Protracted Crises. Eds. Macrae, Joanna and Harmer, Adele (London: Overseas Development Institute, 2004) 1-13.

McKay, John. 'Security and Development'. In International Development: Issues and Challenges, 2nd Ed. Eds. Kingsbury, Damien, McKay, John, Hunt, Janet, McGillivray, Mark and Clarke, Matthew (Basingstoke: Palgrave Macmillan, 2012) 335-360. 
Organisation for Economic Co-operation and Development (OECD). Development Co-operation Report 2002: Efforts and Policies of the Members of the Development Assistance Committee (Paris: OECD Publishing, 2003).

OECD. Development Co-operation Report 2006: Efforts and Policies of the Members of the Development Assistance Committee (Paris: OECD Publishing, 2007).

OECD. Development Co-operation Report 2013: Ending Poverty (Paris: OECD Publishing, 2013).

Oxfam International. 'Quick Impact, Quick Collapse: The Dangers of Militarized Aid in Afghanistan', oxfam.org, www.oxfam.org/sites/www.oxfam.org/ files/quick-impact-quick-collapse-jan-2010.pdf, (26 January 2010) accessed 4 April 2014.

Oxfam International. Whose Aid is it Anyway? Politicizing Aid in Conflicts and Crises (Oxford: Oxfam GB, 2011).

Saferworld UK. 'The Securitisation of Aid? Reclaiming Security to Meet Poor People's Needs'. saferworld.org.uk, www.saferworld.org.uk/ Securitisation\%20briefing\%20pages.pdf, (2011) accessed 4 April 2014.

Shaw, Timothy, MacLean, Sandra and Black, David. 'A Decade of Human Security: What Prospects for Global Governance and New Multilateralisms?' In A Decade of Human Security: Global Governance and New Multilateralisms. Eds. MacLean, Sandra, Black, David and Shaw, Timothy (Aldershort: Ashgate Publishing Limited, 2006) 3-18.

Spear, Joanna and Williams, Paul. 'Conceptualizing the Security-Development Relationship: An Overview of the Debate'. In Security and Development in Global Politics: A Critical Comparison. Eds. Spear, Joanna and Williams, Paul (Washington DC: Georgetown University Press, 2012) 7-33.

Stern, Maria and Öjendal, Joakim. 'Mapping the Security-Development Nexus: Conflict, Complexity, Cacophony, Convergence?' Security Dialogue 41:1 (2010) 5-30.

Stoddard, Abby, Harmer, Adele and DiDomenico, Victoria. 'Providing Aid in Insecure Environments: 2009 Update'. Humanitarian Policy Group, www. odi.org/sites/odi.org.uk/files/odi-assets/publications-opinion-files/4243.pdf, (2009) accessed 20 March 2014.

Tadjbakshs, Shahrbanou and Chenoy, Anuradha. Human Security: Concepts and Implications (Abingdon: Routledge, 2007). 
Thede, Nancy. 'Policy Coherence for Development and Securitisation: Competing Paradigms or Stabilising North-South Hierarchies?' Third World Quarterly 34:5 (2013) 784-799.

United Nations Development Programme. Afghanistan National Human Development Report 2004 - Security With a Human Face: Challenges and Responsibilities (Islamabad: Army Press, 2004).

United Nations Development Programme. Human Development Report 2005: International Cooperation at a Crossroads: Aid, Trade and Security in an Unequal World (Pittsburgh: Hoechstetter Printing Co., 2005). 
This text is taken from The ANU Undergraduate Research Journal, Volume Six, 2014, edited by Jonathon Zapasnik and Alexandra Hogan, published 2015 by ANU eView, The Australian National University, Canberra, Australia. 